Int. J. Electrochem. Sci., 14 (2019) $5661-5678$

International Journal of

ELECTROCHEMICAL

SCIENCE

$\underline{\text { www.electrochemsci.org }}$

Mini review

\title{
Design and Applications of Ratiometric Electrochemical Biosensors
}

\author{
Linlin Hou*, Chunyan Duan and Panpan Ding \\ Henan Province of Key Laboratory of New Optoelectronic Functional Materials, College of Chemistry \\ and Chemical Engineering, Anyang Normal University, Anyang, Henan 455000, People's Republic of \\ China \\ *E-mail: linlin9918@163.com
}

doi: $10.20964 / 2019.06 .74$

Received: 9 March 2019 / Accepted: 12 April 2019 / Published: 10 May 2019

Electrochemical biosensors have been used in the fields of disease diagnosis, environmental monitoring, and food safety. However, the traditional electrochemical biosensors have some shortcomings, such as poor stability and reproducibility. Ratiometric electrochemical biosensors can eliminate the potential interference, provide internal self-calibration, and improve detection sensitivity and selectivity. In this paper, the construction strategies for ratiometric electrochemical biosensors and their applications in biochemical analysis of proteins, nucleic acids, small biological molecules and metal ions are summarized.

Keywords: Ratiometric electrochemical biosensors; signal amplification

\section{$\underline{\text { FULL TEXT }}$}

(C) 2019 The Authors. Published by ESG (www.electrochemsci.org). This article is an open access article distributed under the terms and conditions of the Creative Commons Attribution license (http://creativecommons.org/licenses/by/4.0/). 